\title{
Hardness of Ductile Cast Iron Castings and its Control in Praxis
}

Iveta Vasková, Peter Šebek, Igor Mulik

Technical University of Košice, Faculty of Metallurgy, Letná 9, 04001 Košice, Slovakia. Iveta.vaskova@tuke.sk, Peter.sebek@eurocast.sk,

Foundry is one of the oldest industry branch. In the evolution of humankind it played great role wih always improving mechanical properties of metals and in using of newest knowledges, it still plays one of the key function in all spheres of our lives. We meet everyday with the castings. It is the same if we sit in the car or we are eating the waffle. The production of every single casting needs individual approach for repeatidly achievement of desired material properties. Hardness is one of the basic property of metal materials in common. From hardness depends how easy, or how hard would be given material machined and what kind of materials, tools and machines would we need. In todays world of planning it is a matter of course to demand the same hardness for given material, so that the same machinability could be ensured and costs and machining time were minimalized. It is not always easy to assure this condition in praxis.

Keywords: ductile cast iron, hardness of castings, machinability, statistics

\section{Acknowledgements}

„This work was supported by the Slovak Research and Development agency under the contract no. VEGA $1 / 0498 / 11 “$.

\section{References}

[1] TRYTEK A., ORLOWICZ A.W., MRÓZ M., TUPAJ M.: Examination of cast iron properties by means of then scratch method. Archives of Foundry Engineering, z.2 special, t.12, s.75-80,

[2] HLAVENKA B.: Systematické projektování výrobních systému s využitím počítače, Strojírenská technologie, II. roč., červen 1997, str. 18-20, ISSN 1211-4162

[3] ČESKÁ SPOLEČNOST PRO JAKOST - Aplikace matematicko - statistických metod při rešení rúzných technických problému, Praha 1992, s. 104

[4] BERANEK L., BAČANOVA L., VAŠTA F, ZELENKA A:: Praktické využití statistických metod při navrhování experimentu, Strojirenská technologie, XII. roč., prosinec 2007, str. 22-26, ISSN 1211-4162.

[5] DETAILED REGULATION OF PRODUCTION TECHNOLOGY IN THE COMPANY EUROCAST.

[6] PUERTA F. L., MÁDL J.: Tool Condition Monitoring in Drilling, Manufacturing Technology, I, January 2001, pp. 33-38, ISSN 1213-2489.

[7] MÁDL J., MACHA P.: Cost and Technical Factors in the Optimisation of Machining Processes and Controlling, Manufacturing Technology, V, December 2005, pp. 14-21, ISSN 1213-2489.

[8] TECHNICAL-DELIVERY CONDITIONS FOR CASTINGS, Eurocast Košice s.r.o.

[9] HORÁLEK, V.: Shewhartovy regulačni diagramy a jejich aplikace, Praha 1991.

[10] CHAJDIAK, J.: Štatistika a riadenie kvality. STATIS, Bratislava 1995.

[11] BAKYTOVÁ, H.: Základy štatistiky, Bratislava: ALFA 1975, s. 390 - 415.

[12] VAŠTA F., ZELENKA A.: Návrh systému managementu jakosti v týmové spolupráci útvaru technické př́pravy výroby, Strojirrenská technologie, XIII. roč., záŕí 2008, str. 12 - 17, ISSN 1211-4162.

[13] TOŠENOVSKÝ J., DUDEK M.: Základy statistického spracování dat, Ostrava, Ediční středisko VŠB - TU Ostrava, 2004.

[14] MULIK,I.: Bachelor Thesis, Technical University of Košice, 2011. 